\title{
TRATAMENTO NÃO CIRÚRGICO DE NECROSE PANCREÁTICA INFECTADA
}

Há muitos anos publicamos o primeiro relato existente na literatura sobre um paciente com necrose pancreática infectada que sobreviveu após tratamento clínico estrito, a saber, através de antibioticoterapia. ${ }^{1} \mathrm{O}$ relato foi fortemente criticado, talvez apropriadamente, na medida em que o conceito prevalente era, e continua a ser, que o procedimento recomendado é a necrosectomia e drenagem, aplicada na quase totalidade dos casos. ${ }^{2}$

Há que notar que, no caso, a antibioticoterapia exclusiva não foi uma opção terapêutica, muito menos um experimento não autorizado. $\mathrm{Na}$ verdade o procedimento resultou da recusa irrevogável do paciente em submeter-se a qualquer intervenção cirúrgica por motivação religiosa.

Àquele tempo, mesmo cirurgiões experientes confessavam, em particular, que em raras ocasiões haviam se defrontado com esta mesma situação: pacientes não operados que havia sobrevivido através de antibioticoterapia. No entanto, a publicação de relatos de casos era tida como inaceitável.

Quinze anos e muitos artigos mais tarde a necrose pancreática infectada continua a ser um quadro clínico não trivial e provavelmente nunca será. Nem se pode afirmar que o tratamento não cirúrgico tornou-se aceitável.

No entanto, avanços na radiologia intervencionista e outras formas de manejo minimamente invasivo beneficiaram significativamente pacientes com focos infecciosos profundamente situados, inclusive àqueles associados com a pancreatite aguda. ${ }^{3,4}$

É evidente que o manejo minimamanete invasivo não é o tratamento padrão para necrose pancreática infectada e que o debridamento cirúrgico do foco contaminado continua a produzir os melhores resultados, com mortalidade entre 20 e 25\%.2,5 Mas o uso de procedimentos minima- mente invasivos continua a crescer em alguns centros médicos e pode, eventualmente converter-se numa alternativa geralmente aceita.

Necroses infectadas disseminadas e focos bacterianos mal localizados não se prestam a manejo percutâneo fácil, de modo que tratamentos não clássicos deveriam permanecer restritos a centros com interesse e competência nesta área. A mortalidade associada à laparoscopia ou à drenagem percutânea ${ }^{3,4}$ tendem a ser maiores que as dos melhores centros cirúrgicos. ${ }^{2.5}$ No entanto, à medida que a técnica se aperfeiçoa e resultados melhores começam a se tornar mais freqüentes, é concebível que as técnicas não clássicas possam se tornar terapias de eleição.

A antibioticoterapia exclusiva, tal como recentemente a discutiram Amico et al, ${ }^{6}$ é defendida por alguns, mas é pouco provável que venha a se tornar uma opção de primeira linha, a menos que surjam novos fármacos ou novos protocolos de prescrição muito mais eficientes como tratamento destas complexas e perigosas lesões intra- e retroperitoneais. Pacientes em bom estado clínico são os que apresentam melhores resultados, de acordo com achados preliminares, em concordância com a nossa experiência ${ }^{1}$. No entanto estes são também os pacientes com resultados favoráveis quando submetidos a praticamente qualquer modalidade terapêutica.

A radiologia intervencionista já é aconselhada para pacientes metabólica e hemodinamicamente instáveis, bem como para outros para os quais não seja recomendável o procedimento cirúrgico ${ }^{4,5}$. Este tema pode em breve deixar de ser controverso à medida que novas provas mais conclusivas apóiem as respectivas revisões de recomendações terapêuticas. 